Check for updates

Cite this: Mater. Adv., 2020, 1,2236

Received 2nd July 2020

Accepted 2nd September 2020

DOI: $10.1039 / \mathrm{d} 0 \mathrm{ma} 00475 \mathrm{~h}$

rsc.li/materials-advances

\section{Magic-angle spinning NMR spectroscopy provides insight into the impact of small molecule uptake by G-quartet hydrogels $\dagger$}

\author{
G. N. Manjunatha Reddy, (D) $\ddagger^{*^{a}}$ Gretchen M. Peters, ${ }^{b}$ Ben P. Tatman, (D) ${ }^{a}$ \\ Teena S. Rajan, ${ }^{c}$ Si Min Kock, ${ }^{c}$ Jing Zhang, ${ }^{c}$ Bruno G. Frenguelli, ${ }^{d}$ \\ Jeffery T. Davis, (D) ${ }^{b}$ Andrew Marsh (D) *c and Steven P. Brown (D) *a
}

\begin{abstract}
Small molecule guests influence the functional properties of supramolecular hydrogels. Molecular-level understanding of sol-gel compositions and structures is challenging due to the lack of long-range order and the inherently heterogeneous sol-gel interface. Here, we employ multinuclear $\left({ }^{7} \mathrm{Li},{ }^{11} \mathrm{~B},{ }^{23} \mathrm{Na},{ }^{39} \mathrm{~K}\right.$ and ${ }^{133} \mathrm{Cs}$ ) gel-state magic-angle spinning (MAS) NMR spectroscopy to gain insight into the roles of alkali cations and borate anions in the gelation of guanosine (G)-quartets (G4). The MAS NMR spectra of alkali metal ions enabled the cations associated with G-quartets to be distinguished from the free cations. Combined ${ }^{11} \mathrm{~B}$ MAS NMR and modeling studies allowed cis and trans configurations of guanosine-borate (GB) diesters to be characterized, thus providing a complementary structural insight that indicates that the GB cis diester favours gelation. In addition, the multinuclear MAS NMR strategy is applied to understand the uptake process of biologically relevant small molecules into GB hydrogels. G4. $\mathrm{K}^{+}$borate hydrogel can absorb up to 0.3 equivalent of cationic methylene blue (MB) without a significant disruption of the G4 fibrils that make up the gel, whereas the addition of over 0.3 equivalents of MB to the same gel leads to a gel-to-sol transition. By comparison, uptake of heterocyclic molecules such as adenine, cytosine and 1-methylthymine into $\mathrm{G} 4 \cdot \mathrm{Na}^{+}$borate hydrogels leads to stable and clear gels while increasing the solubility of the nucleobases as compared to the solubility of the same compounds in water. G4. $\mathrm{Na}^{+}$gel can uptake one equiv. of adenine with minimal disruption to the hydrogel framework, thus enhancing the adenine solubility up to an order of magnitude as compared to water. Multinuclear $\left({ }^{1} \mathrm{H},{ }^{11} \mathrm{~B}\right.$ and $\left.{ }^{23} \mathrm{Na}\right)$ MAS NMR analysis and vial inversion tests revealed that the nucleobases are embedded into pores of the solution phase rather than being closely interacting with the G4 fibrils that make up the gel phase. These results indicate that G4 hydrogels have potential applications as carrier systems for small molecule drugs.
\end{abstract}

\footnotetext{
${ }^{a}$ Department of Physics, University of Warwick, Coventry CV4 7AL, UK. E-mail: gnm.reddy@univ-lille.fr, S.P.Brown@warwick.ac.uk

${ }^{b}$ Department of Chemistry and Biochemistry, University of Maryland, College Park, Maryland, MD 20742, USA

${ }^{c}$ Department of Chemistry and, University of Warwick, Coventry CV4 7AL, UK. E-mail: a.marsh@warwick.ac.uk

${ }^{d}$ School of Life Sciences, University of Warwick, Coventry CV4 7AL, UK

$\dagger$ Electronic supplementary information (ESI) available: MAS NMR spectra of alkali metal cations, determination of ${ }^{11} \mathrm{~B}$ isotropic chemical shifts and quadrupolar parameters, DFT calculated structures of guanosine borate mono- and diesters, tables of nucleobase solubility assays, and photographs of inverted vials containing guanosine borate gels before and after the incorporation of small molecules. See DOI: 10.1039/d0ma00475h

\# Present address: Department of Chemistry, University of Lille, CNRS, Centrale Lille Institut, Univ. Artois, UMR 8181-UCCS-Unité de Catalyse et Chimie du Solide, F-59000, Villeneuve d'Ascq, France.
}

\section{Introduction}

Self-assembly of small molecules into functional supramolecular assemblies is of great current interest to develop materials for biomedical, environmental remediation and optoelectronic applications. ${ }^{1-6}$ In particular, biologically relevant molecules such as peptides, nucleobases, starch and polysaccharides have garnered attention to develop functional hydrogels for biomedical and clinical applications. ${ }^{7-11}$ For example, hydrogel delivery systems can be useful for the controlled uptake and release of drug molecules, so as to achieve therapeutically beneficial outcomes. Upon the addition of drug molecules into the hydrogels, the physicochemical properties of these systems ensure the compatibility and controllability of the drug delivery. Hydrogels differing in their sol-gel composition, archetype, 
structure and function have been previously developed and used for drug delivery applications. ${ }^{12}$

Guanosine (G) and its derivatives exhibit rich supramolecular chemistry. ${ }^{13-16}$ The hierarchy of distinct quartet- and ribbonlike structures formed by G-derivatives have been employed to develop stimuli-responsive gels, electrochemical sensors, antiviral gels, synthetic ion channels and liquid crystalline phases. ${ }^{9,14,17-20}$ Davis and colleagues developed stable and long-lived hydrogels by mixing guanosine and alkali metal borate salts in water $\left(\mathrm{G} 4 \cdot \mathrm{M}^{+}\right.$borate hydrogel, Scheme 1$) \cdot{ }^{21,22}$ The mechanism of gelation (Scheme 1) was corroborated by cryogenic transmission electron microscopy (cryo-TEM), rheology, powder X-ray diffraction (PXRD), small-angle neutron scattering (SANS), gel- and solid-state NMR spectroscopy measurements and analyses. ${ }^{21,22}$ These guanosine borate (GB) hydrogels exhibit unique structural properties that are favourable for absorbing guest species: elongated G4-quartet fibrils of GB gels can bind to G-quadruplex ligands such as thioflavin-T and methylene blue, and allow the cations to exchange between the gel network and solution phase. ${ }^{21,22}$ In addition, the GB gels can undergo exchange reactions with cis diols, facilitating covalent incorporation of compounds containing 1,2-cis-diols. These beneficial properties associated with GB gels enabled the development of materials for cell growth, ${ }^{23}$ flexible sensors, ${ }^{19}$<smiles>Nc1nc2c(ncn2C2OC(CO)C(O)C2O)c(=O)[nH]1</smiles>

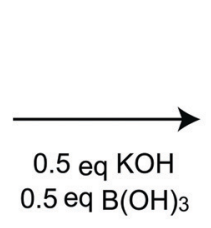
0.5 eq $\mathrm{B}(\mathrm{OH})_{3}$

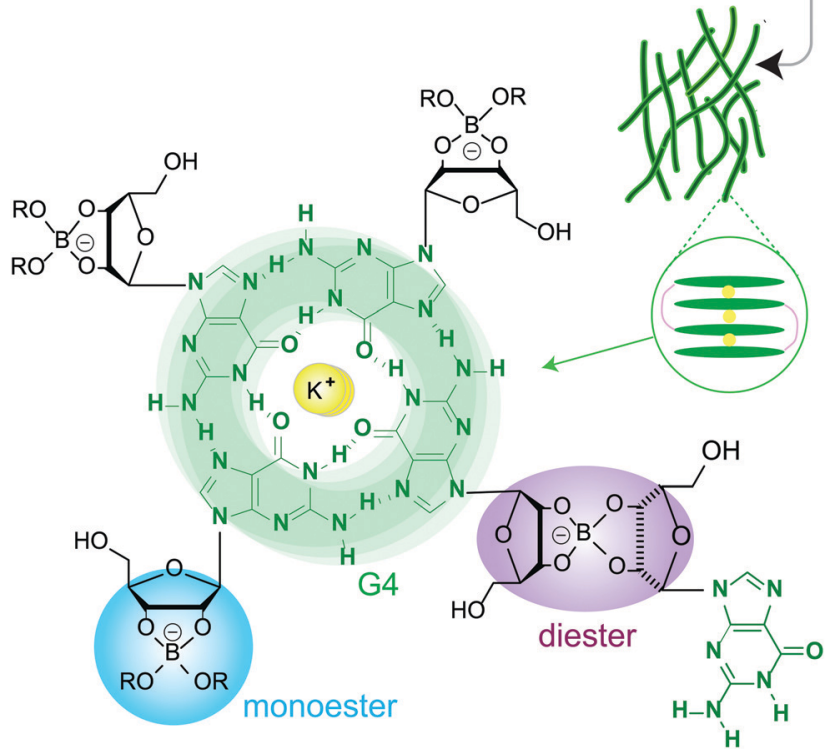

Scheme 1 Schematic diagram of the gelation mechanism of $G 4 \cdot M^{+}\left(M^{+}=\right.$ $\mathrm{K}^{+}, \mathrm{Na}^{+}$) hydrogels upon mixing guanosine $(\mathrm{G})$ with metal borate salts. Guanosine borate cis diesters favour gelation by covalently cross-linking stacked G-quartets. wound healing, ${ }^{10}$ and environmental remediation. ${ }^{24}$ The commonality associated with these functional soft materials is that their bulk properties depend strongly on the molecular interactions at the sol-gel interfaces. Therefore, molecular-level understanding of sol-gel compositions and structures is expected to help with better formulation of such materials, for example, hydrogels for targeted biomedical, environmental remediation and optoelectronics applications.

The functional properties of gelator molecules depend strongly on the key structure directing interactions that govern the physicochemical properties of hydrogels as well as the intermolecular interactions between guest molecules and hydrogels. Establishing the structure-function relationships in responsive and dynamic hydrogels represents a challenge. This is due, at least in part, to the compositional and structural heterogeneity associated with the reactive sol-gel interfaces. Stability and integrity of gels is often rationalized by understanding their melting and rheological properties, and insights into the structures of gel networks, gelator molecules and their aggregates at different length scales can be obtained by different characterization techniques such as X-ray scattering, electron microscopy, single particle reconstruction and NMR spectroscopy. ${ }^{6,25-28}$ In this respect, MAS NMR spectroscopy provides complementary information into the short-range structures and interactions in both sol- and gel domains of soft materials. ${ }^{26,29-33} \mathrm{NMR}$ chemical shifts and dipole-dipole couplings are sensitive to local chemical environments and interatomic distances, which provide information on the host-guest interactions, compositions and structures, and packing interactions in supramolecular assemblies. ${ }^{34-36}$ For example, recent MAS NMR studies enabled distinct quartet and ribbon-like structures to be elucidated, ${ }^{37-40}$ and the sol-gel compositions of $\mathrm{G} 4 \cdot \mathrm{M}^{+}$borate hydrogels to be distinguished and identified. ${ }^{21,22}$

Here, molecular-level insight into the impact of small molecule uptake by different $\mathrm{G} 4 \cdot \mathrm{M}^{+}$borate hydrogels (Scheme 1 ) is obtained and compared. The guest molecules (Scheme 2) are chosen on the basis of their structures and swelling properties into the GB hydrogels. The absorption properties of these small<smiles>CN(C)c1ccc2c(c1)Sc1cc(N(C)C)ccc1N2</smiles>

methylene blue $(\mathrm{MB})$<smiles>Nc1ccn(C2OC(O)C(O)C2O)c(=O)n1</smiles>

cytidine<smiles>Nc1ncnc2[nH]cnc12</smiles>

adenine<smiles>Nc1nc2[nH]cnc2c(=O)[nH]1</smiles>

guanine<smiles></smiles>

cytosine<smiles>Cc1cn(C)c(=O)[nH]c1=O</smiles>

1-methylthymine
Scheme 2 Chemical structures of cationic and neutral molecules added into $\mathrm{G} 4 \cdot \mathrm{M}^{+}\left(\mathrm{M}^{+}=\mathrm{K}^{+}, \mathrm{Na}\right)$ borate gels. Cytidine is used as an external standard to quantify incorporation of adenine into $\mathrm{G} 4 \cdot \mathrm{K}^{+}$borate gels. 
molecules are characterized $e x$ situ by employing solution- and gel-state NMR spectroscopy, and corroborated by vial inversion tests. Notably, multinuclear $\left({ }^{7} \mathrm{Li},{ }^{23} \mathrm{Na},{ }^{39} \mathrm{~K}\right.$ and $\left.{ }^{133} \mathrm{Cs}\right)$ MAS NMR spectroscopy enabled different distributions of cations in sol-gel networks, and their roles in the gelation properties of GB gels, to be distinguished and analyzed. In addition, ${ }^{1} \mathrm{H}$ and ${ }^{11} \mathrm{~B}$ MAS NMR has been employed to probe the changes in the local structures of the borate anions that help to hold together the G4 fibrils in GB hydrogels. ${ }^{11} \mathrm{~B}$ MAS NMR results are complemented by density functional theory (DFT) calculations, which showed that the GB cis diesters favour the gelation as compared to the GB trans diester and GB monoester components. Emphasis is placed on understanding how changes occur in the sol-gel interfaces upon the addition of cationic dye (methylene blue, MB) and heterocyclic nucleobases such as adenine, cytosine and 1-methylthymine into $\mathrm{G} 4 \cdot \mathrm{M}^{+}\left(\mathrm{M}^{+}=\mathrm{K}^{+}\right.$, $\mathrm{Na}^{+}$) gels.

\section{Experimental section}

\section{Preparation and addition of small molecules to $\mathrm{G} 4 \cdot \mathrm{M}^{+}$borate gels}

G-Quartet borate hydrogels were prepared according to the procedure described in our previous work. ${ }^{21,22}$ Guanosine $\left(\mathrm{G} \cdot 2 \mathrm{H}_{2} \mathrm{O}\right)$, boric acid, $\mathrm{LiOH}, \mathrm{NaOH}, \mathrm{KOH}$ and $\mathrm{CsOH}$ were purchased from Sigma Aldrich Gillingham UK and used as received. Stock solutions of boric acid $(200 \mathrm{mM})$ and alkali metal hydroxides $(200 \mathrm{mM})$ were prepared in low conductivity Millipore water. To a solution of sonicated guanosine $(72 \mathrm{mM})$ powder in water, half an equivalent of alkali metal borate salt (36 $\mathrm{mM}$ ) was added. The glass vial containing the milky solution was placed on a hot plate and slowly heated up to $90{ }^{\circ} \mathrm{C}$ with continuous stirring until a clear solution was observed. The hot saturated solution was allowed to cool to room temperature. A 'tap test' was carried out whereby each gel was given a narrow tap and then inverted to observe whether it remained clear and self-standing. For the studies involving absorption or uptake of small molecules by the hydrogel, the hot saturated solution of $\mathrm{G} 4 \cdot \mathrm{K}^{+}$hydrogel was pipetted into vials containing different concentrations of methylene blue, and the resulting solutions were manually stirred on a hot plate and then allowed to cool to room temperature. Nucleobase solubility assays were separately carried out for adenine, guanine, cytosine and 1-methylthymine in water, and in G4. $\mathrm{K}^{+}$and $\mathrm{G} 4$. $\mathrm{Na}^{+}$gels. Saturated solutions of $\mathrm{G} 4 \cdot \mathrm{K}^{+}$and $\mathrm{G} 4 \cdot \mathrm{Na}^{+}$gels, prepared either in $\mathrm{D}_{2} \mathrm{O}$ or Millipore water, were pipetted into vials containing increasing concentration of the nucleobase. Each vial was then reheated and sonicated until the solid powders of nucleobases dissolved and the resultant solution was allowed to cool to room temperature. Solubility of nucleobase molecules was monitored over a week.

\section{Characterization}

Gels were heated to their sol-gel transition temperature $\left(\sim 90{ }^{\circ} \mathrm{C}\right.$ to ensure a clear solution-like material) to inject them into $4 \mathrm{~mm}$ (outer diameter) zirconia rotors containing an inbuilt bottom insert. A procedure for determining melting temperatures $\left(T_{\mathrm{m}}\right)$ of different $\mathrm{G} 4 \cdot \mathrm{M}^{+}$borate gels is described in our previous study. ${ }^{22}$ The rotors were packed with $\sim 20 \mu \mathrm{L}$ of hydrogel using a top insert-screw-lid system and then with a Kel-F cap to ensure the close-fitting. Unless specified, the spinning frequency was $5 \mathrm{kHz}$ in all MAS NMR experiments. ${ }^{7} \mathrm{Li},{ }^{23} \mathrm{Na},{ }^{39} \mathrm{~K}$ and ${ }^{133} \mathrm{Cs}$ MAS NMR experiments were carried out at $20 \mathrm{~T}$ with a Bruker Avance III spectrometer (Larmor frequencies were ${ }^{1} \mathrm{H}=850.2 \mathrm{MHz},{ }^{7} \mathrm{Li}=330.3 \mathrm{MHz},{ }^{23} \mathrm{Na}=224.8 \mathrm{MHz}$, ${ }^{39} \mathrm{~K}=39.7 \mathrm{MHz}$, and ${ }^{133} \mathrm{Cs}=111.5 \mathrm{MHz}$ ) and on a double resonance H-X MAS probe. For ${ }^{7} \mathrm{Li},{ }^{23} \mathrm{Na},{ }^{39} \mathrm{~K}$ and ${ }^{133} \mathrm{Cs}$ MAS NMR, signal averaging was performed over 512, 2048, 20480 and 4096 co-added transients for a recycle delay of 2 , 2, 1 and 5 seconds, respectively. The ${ }^{7} \mathrm{Li},{ }^{23} \mathrm{Na},{ }^{39} \mathrm{~K}$ and ${ }^{133} \mathrm{Cs}$ chemical shifts were calibrated using aqueous solutions containing $100 \mathrm{mM}$ of $\mathrm{LiCl}, \mathrm{NaCl}, \mathrm{KCl}$ and $\mathrm{CsNO}_{3}$ referenced to $0.0 \mathrm{ppm}$, respectively. $1 \mathrm{D}{ }^{11} \mathrm{~B}$ NMR experiments were carried out at different magnetic field strengths: $11.7 \mathrm{~T}$ with a Bruker Avance III $\left({ }^{1} \mathrm{H}=500.1 \mathrm{MHz},{ }^{11} \mathrm{~B}=160.5 \mathrm{MHz}\right), 14.1 \mathrm{~T}$ with a Bruker Avance $\mathrm{II}^{+}\left({ }^{1} \mathrm{H}=599.4 \mathrm{MHz},{ }^{11} \mathrm{~B}=192.3 \mathrm{MHz}\right)$ and $20.0 \mathrm{~T}$ with a Bruker Avance III $\left({ }^{1} \mathrm{H}=850.2 \mathrm{MHz},{ }^{11} \mathrm{~B}=272.8 \mathrm{MHz}\right)$ spectrometer equipped with a $4 \mathrm{~mm}$ HXY (in double resonance configuration), $4 \mathrm{~mm} \mathrm{HX}$ and $4 \mathrm{~mm}$ HX MAS probe, respectively. The ${ }^{11} \mathrm{~B} \pi / 2$ pulse length was $2.5 \mu \mathrm{s}$. Two-Pulse Phase Modulation (TPPM) decoupling ${ }^{41}$ was applied during the acquisition with a ${ }^{1} \mathrm{H} \pi$ pulse duration of $5 \mu \mathrm{s}$ at $11.7 \mathrm{~T}$ and $14.1 \mathrm{~T}$, and $6 \mu \mathrm{s}$ at $20 \mathrm{~T}$, corresponding to a ${ }^{1} \mathrm{H}$ nutation frequency of $100 \mathrm{kHz}$ for 11.7 and $14.1 \mathrm{~T}$, and $85 \mathrm{kHz}$ for $20 \mathrm{~T} .{ }^{11} \mathrm{~B}$ MAS NMR spectra were acquired by co-adding 2048 transients with a recycle delay of 4 seconds, corresponding to an experimental time of $2 \mathrm{~h}$. The ${ }^{11} \mathrm{~B}$ chemical shifts of guanosine borate esters were referenced to $\mathrm{NaBH}_{4}$ at $-42.06 \mathrm{ppm}$ as a secondary reference to the primary reference using $\mathrm{BF}_{3} \mathrm{Et}_{2} \mathrm{O}$ at $0.0 \mathrm{ppm}^{42}$ For the gels prepared using $\mathrm{D}_{2} \mathrm{O}$, one-pulse ${ }^{1} \mathrm{H}$ NMR spectra were recorded using either a Bruker Avance III, 9.4 T $\left({ }^{1} \mathrm{H}, 400 \mathrm{MHz}\right)$ or a Bruker Avance $11.7 \mathrm{~T}\left({ }^{1} \mathrm{H}, 600 \mathrm{MHz}\right)$ spectrometer. The ${ }^{1} \mathrm{H} \pi / 2$ pulse lengths were $12.35 \mu \mathrm{s}$ and $11.4 \mu \mathrm{s}$, respectively. Signal averaging was performed using 256 co-added transients with a recycle delay of $1 \mathrm{~s}$, corresponding to a total experimental time of 15 minutes.

\section{Density functional theory (DFT) calculations}

To understand different distributions of ${ }^{11} \mathrm{~B}$ chemical shifts of hydrogels, DFT calculations were carried out on a GB monoester, and cis and trans isomers of diesters. All calculations were performed using the Gaussian 09 package. ${ }^{43}$ The GB mono and dimer structures were optimized to a ground-state equilibrium geometry using the B3LYP functional and aug-cc-pvdz basis set. Using the geometry optimized dimer structure, conformationally different GB dimers were generated by constraining the $\mathrm{C}-\mathrm{C}-\mathrm{C}-\mathrm{C}$ dihedral angle between purine and sugar moieties into cis ( $\mathrm{G}$ moieties facing the same side of borate ester) and trans (G moieties on the opposite sides of the borate ester) conformations. DFT geometry optimized structures of GB monoester, and cis and trans GB dimers were then used to 
calculate NMR shieldings using the gauge-independent atomic orbital (GIAO) method with B3LYP/6-31G functional and basis set. DFT-calculated ${ }^{11} \mathrm{~B}$ shieldings were referenced to the ${ }^{11} \mathrm{~B}$ shifts of $\mathrm{B}_{2} \mathrm{H}_{6}$ (calculated using the same B3LYP/6-21G functional) included in the Gaussian 09 package. ${ }^{43}$ DFT-calculated ${ }^{11} \mathrm{~B}$ shieldings were plotted against experimental ${ }^{11} \mathrm{~B}$ shifts ${ }^{44-46}$ and regression analysis was carried out by constraining the slope to 1.0. This analysis leads to linear correlation between the experimental and DFT calculated ${ }^{11} \mathrm{~B}$ shifts with an intercept of $31.0 \mathrm{ppm}$. In order to compare with the experimental isotropic ${ }^{11} \mathrm{~B}$ shifts shown in the tables, $31.0 \mathrm{ppm}$ should be added to the DFT calculated ${ }^{11} \mathrm{~B}$ shieldings.

\section{Results and discussion}

\section{Roles of cations and borate anions in the gelation of G-borate} dimers

We used MAS NMR to separately examine the roles of alkali metal cations and borate anions in the gelation process that gives rise to $\mathrm{G} 4 \cdot \mathrm{M}^{+}$borate gels. Although boron cross linking of guanosine units in different G-quartet layers apparently enhances the stability of GB gels, the templating cation's size and charge is crucially important in the gelation. In a previous study, we showed that the $\mathrm{G} 4 \cdot \mathrm{K}^{+}$borate gel exhibited a remarkable stability, relative to $\mathrm{G} 4 \cdot \mathrm{M}^{+}$gels made with the other alkali metal cations. ${ }^{21,22}$ To better understand the key role of alkali metal cations in stabilizing these functional hydrogels, a series of $\mathrm{G} 4 \cdot \mathrm{M}^{+}$gels were prepared with $\mathrm{LiB}\left(\mathrm{OH}_{4}\right), \mathrm{NaB}\left(\mathrm{OH}_{4}\right), \mathrm{KB}\left(\mathrm{OH}_{4}\right)$ and $\mathrm{CsB}\left(\mathrm{OH}_{4}\right)$ salts and characterized using ${ }^{7} \mathrm{Li},{ }^{23} \mathrm{Na},{ }^{39} \mathrm{~K}$ and ${ }^{133}$ Cs MAS NMR, respectively (ESI, $\dagger$ Fig. S1). A narrow signal observed at $0 \mathrm{ppm}$ in the ${ }^{7} \mathrm{Li}$ MAS NMR spectrum of the $\mathrm{G} 4 \cdot \mathrm{Li}^{+}$ borate gel indicates the presence of free $\mathrm{Li}^{+}$ions in a solutionlike environment. In contrast, the ${ }^{133}$ Cs MAS NMR spectrum of a G4. $\mathrm{Cs}^{+}$gel shows multiple signals, indicating that the $\mathrm{Cs}^{+}$ ions are dispersed into different local chemical environments of this sol-gel material: the relatively broad signals at 50 and $42 \mathrm{ppm}$ originate from different distributions of $\mathrm{Cs}^{+}$ions in the G4 network (gel) and in the cloudy precipitate that is formed along with the gel, while the narrow signal at $12 \mathrm{ppm}$ is due to free $\mathrm{Cs}^{+}$ions in the solution phase. Signal integrals obtained from lineshape fitting analysis revealed that $73 \pm 6 \%$ of the $\mathrm{Cs}^{+}$ was in the gel phase and $27 \pm 6 \%$ was in solution. In the ${ }^{39} \mathrm{~K}$ MAS NMR spectrum of the $\mathrm{G} 4 \cdot \mathrm{K}^{+}$borate gel (Fig. 1a), partially resolved signals are observed with a broad intensity at $8 \mathrm{ppm}$, indicative of $\mathrm{K}^{+}$ions located within the central G4-channel, ${ }^{47}$ and a relatively narrow signal at $\sim 0 \mathrm{ppm}$ ascribed to free $\mathrm{K}^{+}$ ions in solution phase. Lineshape fitting analysis of these signals enabled the quantification of $\mathrm{K}^{+}$ions in the sol and gel phases (the narrow and broad signals in the presented MAS NMR spectra are associated with free cations in the solutionlike environment (herein called sol) and cations associated with the G4 network (herein called gel), respectively), which were $53 \pm 8 \%$ and $47 \pm 8 \%$, respectively. To further confirm the assignments, a ${ }^{39} \mathrm{~K}$ NMR spectrum was acquired after soaking the $\mathrm{G} 4 \cdot \mathrm{K}^{+}$borate gel overnight in a solution containing an
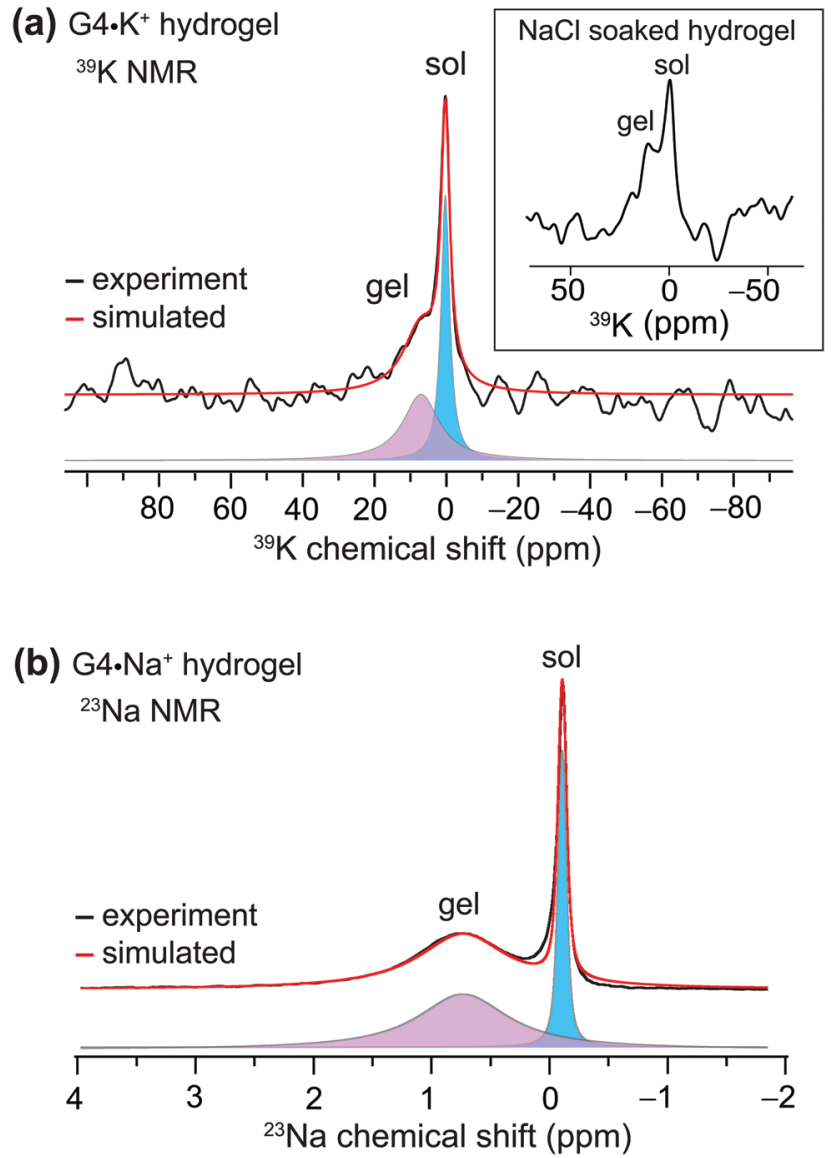

Fig. 1 Gel-state 1D MAS NMR spectra of $20 \mu \mathrm{L} \mathrm{G4} \cdot \mathrm{M}^{+}$hydrogels acquired at $20 \mathrm{~T}$ with their deconvolution into broad and narrow components: (a) ${ }^{39} \mathrm{~K}$ MAS $(5 \mathrm{kHz}) \mathrm{NMR}$ spectrum of $\mathrm{G} 4 \cdot \mathrm{K}^{+}$gel and (b) ${ }^{23} \mathrm{Na}$ MAS $(5 \mathrm{kHz})$ NMR spectrum of G4. Na ${ }^{+}$gel. The inset in (a) depicts a ${ }^{39} \mathrm{~K}$ MAS NMR spectrum of a G4. $\mathrm{K}^{+}$borate gel that had been soaked overnight in $155 \mathrm{mM}$ $\mathrm{NaCl}$ solution, acquired under the same conditions. The narrow and broad signals originate from the free cations in the solution-like environment (herein called sol) and cations associated with the G4 network (herein called gel), respectively.

excess of $\mathrm{NaCl}$ (Fig. 1a, inset). The $\mathrm{G} 4 \cdot \mathrm{K}^{+}$borate gel soaked in $155 \mathrm{mM} \mathrm{NaCl}$ solution showed a significant reduction in the intensity of the narrow signal, confirming that the $\mathrm{K}^{+}$ions in the sol-phase had exchanged with the $\mathrm{Na}^{+}$ions in the bath solution, while the $\mathrm{K}^{+}$ions bound to $\mathrm{G} 4$ channels are retained due to their stronger binding affinity to G-quartets within the $\mathrm{G} 4 \cdot \mathrm{K}^{+}$borate gel. Based on these observations, the narrow signal in the ${ }^{39} \mathrm{~K}$ spectrum is assigned to the $\mathrm{K}^{+}$ions in an aqueous environment and the broad signal is assigned to $\mathrm{K}^{+}$ ions in the G4-channel.

Next, we studied the distributions of $\mathrm{Na}^{+}$cations in the sol- and gel phases of $\mathrm{G} 4 \cdot \mathrm{Na}^{+}$borate gel. In the ${ }^{23} \mathrm{Na}$ MAS spectrum of $\mathrm{G} 4 \cdot \mathrm{Na}^{+}$borate gel, two signals are observed (Fig. 1b): the broad signal centered at $0.8 \mathrm{ppm}$ is attributed to the $\mathrm{Na}^{+}$ions in the G4-channel, and a narrow signal in the vicinity of $0 \mathrm{ppm}$ is assigned to $\mathrm{Na}^{+}$ions in solution phase. Lineshape analysis of the ${ }^{23} \mathrm{Na}$ signals enabled the quantification of $\mathrm{Na}^{+}$ions in the sol and gel phases, which were $31 \pm 4 \%$ 
(a) $\mathrm{G} 4 \cdot \mathrm{K}^{+}$hydrogel
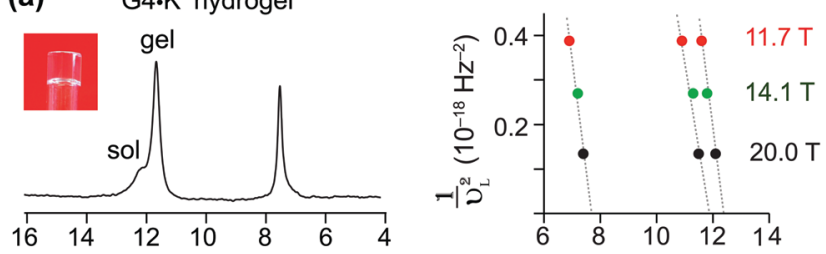

(b)
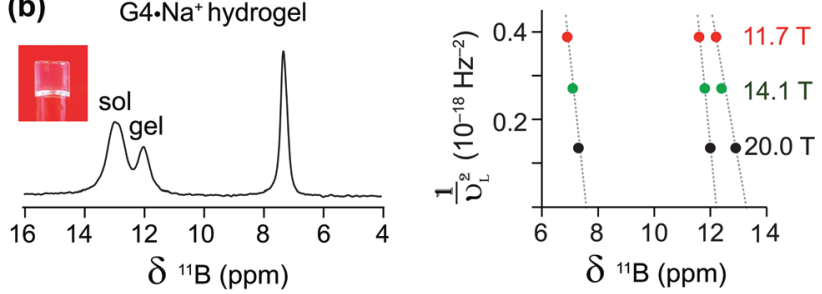

Fig. 2 Gel-state 1D ${ }^{11} \mathrm{~B}$ MAS $(5 \mathrm{kHz})$ NMR spectra of $20 \mu \mathrm{L} G 4 \cdot \mathrm{M}^{+}$ hydrogels acquired at $20 \mathrm{~T}$ using ${ }^{1} \mathrm{H}$ decoupling. The experimental ${ }^{11} \mathrm{~B}$ NMR shifts of (a) G4. $\mathrm{K}^{+}$and (b) G4. $\mathrm{Na}^{+}$gels obtained at different magnetic fields are plotted as a function of the inverse squared Larmor frequency $\left(\nu_{\mathrm{L}}{ }^{2}\right)$ for both the GB mono (6-8 ppm) and diester signals (11-14 ppm). Sol and gel ${ }^{11} \mathrm{~B}$ signals refer to borate mono- and diesters in a solution-like environment and in a G4 network, respectively.

and $69 \pm 4 \%$, respectively. These results are corroborated by our previous studies, which showed that $\mathrm{K}^{+}$and $\mathrm{Na}^{+}$ions stabilize G-quartets as compared to $\mathrm{Li}^{+}$and $\mathrm{Cs}^{+}$ions, ${ }^{21,22}$ and is consistent with the rheological studies, which showed that the $\mathrm{G} 4 \cdot \mathrm{K}^{+}$gel has a high storage modulus $\left(G^{\prime}, \sim 11 \mathrm{kPa}\right)$ that is an order of magnitude larger than the loss modulus $\left(G^{\prime \prime}\right)$, whereas the $\mathrm{G} 4 \cdot \mathrm{Li}^{+}$gel exhibited a $G^{\prime}$ much closer in size to $G^{\prime \prime}$ (Fig. 3, ref. 22). Therefore, based on the results of these above NMR studies and our previous rheology studies, G4 $\cdot \mathrm{K}^{+}$ and $\mathrm{G} 4 \cdot \mathrm{Na}^{+}$gels were chosen for study of the impact of small molecules uptake on the gelation properties.

Complementary insight into the solvent-associated (sol) or G4-network-associated (gel) compositions and structures of G4. $\mathrm{M}^{+}$borate hydrogels were obtained by analyzing ${ }^{11} \mathrm{~B}$ MAS NMR spectra. ${ }^{11} \mathrm{~B}$ (spin 3/2, natural abundance $80.5 \%$ ) MAS NMR has been shown to be a powerful probe for characterizing local boron environments in ion exchange resins, boric acid esters and hydrogels. ${ }^{21,22,42,48-50}$ The ${ }^{11} \mathrm{~B}$ MAS NMR spectra of $\mathrm{G} 4 \cdot \mathrm{Na}^{+}$ and $\mathrm{G} 4 \cdot \mathrm{K}^{+}$borate gels recorded at $20 \mathrm{~T}$ (Fig. 2) showed different

${ }^{11} \mathrm{~B}$ shifts, which could be assigned to tetracoordinated borate anions in both the G4 gel network and in a solution-like environment. These experimental shifts $\left(\delta_{\text {expt }}\right)$ are expected to have contributions from the isotropic ${ }^{11} \mathrm{~B}$ chemical shifts $\left(\delta_{\text {iso }}^{\mathrm{CS}}\right)$ and isotropic second order quadrupolar induced shifts $\left(\delta_{\text {iso }}^{\mathrm{Q}}\right)$. Graphical plots of ${ }^{11} \mathrm{~B}$ shifts measured at different magnetic fields (11.7 T, 14.1 $\mathrm{T}$ and $20 \mathrm{~T})$ as a function of inverse squared Larmor frequency $\left(\nu_{\mathrm{L}}^{2}\right)$ are presented in Fig. 2 to the right of the ${ }^{11} \mathrm{~B}$ MAS NMR spectra. Similar ${ }^{11} \mathrm{~B}$ MAS NMR spectra of $\mathrm{G} 4 \cdot \mathrm{Li}^{+}$ and $\mathrm{G} 4 \cdot \mathrm{Cs}^{+}$gels are presented in the ESI $\dagger$ (Fig. S2). The isotropic ${ }^{11} \mathrm{~B}$ chemical shifts of the mono- and diester signals can be obtained directly from where the extrapolated dashed lines intercept the chemical shift axes (ESI, $\dagger$ Section S2, Table S1). The quadrupolar product $\left(P_{\mathrm{Q}}\right)$ can be calculated accordingly by the following equation, ${ }^{51-53}$

$$
\delta_{\text {expt }}=\delta_{\text {iso }}^{\text {CS }}-\frac{1}{40}\left(\frac{P_{\mathrm{Q}}}{v_{\mathrm{L}}}\right)^{2} \times 10^{6}
$$

The $\delta_{\text {iso }}^{\mathrm{CS}}$ and $P_{\mathrm{Q}}$ values obtained by analyzing the ${ }^{11} \mathrm{~B}$ MAS spectra acquired at three different magnetic fields (Table 1) indicate subtle, but detectable, differences in the local boron environments of the $\mathrm{G} 4 \cdot \mathrm{Na}^{+}$and $\mathrm{G} 4 \cdot \mathrm{K}^{+}$gels, presumably due to the identity of the countercation. The ${ }^{11} \mathrm{~B}$ isotropic chemical shifts and quadrupolar interaction parameters of tetrahedrally coordinated borate anions are in agreement with the analogous tetracoordinated borate anions presented in the literature ( $\delta_{\text {iso }}$ in the range of $0.4-12.4 \mathrm{ppm}$ and quadrupolar coupling constants in the range of $0.9-1.7 \mathrm{MHz}) .{ }^{49}$ The ${ }^{11} \mathrm{~B}$ isotropic signals at 7.5 and $7.7 \mathrm{ppm}$ were attributed to borate monoesters in the ${ }^{11} \mathrm{~B}$ MAS NMR spectra of $\mathrm{G} 4 \cdot \mathrm{Na}^{+}$and $\mathrm{G} 4 \cdot \mathrm{K}^{+}$gels, respectively (Fig. 2 and Table 1 ). In comparison, pairs of signals at 12.2 and $13.2 \mathrm{ppm}$, and at 11.8 and 12.4 are ascribed to different diastereomeric borate diesters that are in cis and trans conformations with respect to guanosine moieties, respectively, in the ${ }^{11} \mathrm{~B}$ NMR spectra of $\mathrm{G} 4 \cdot \mathrm{Na}^{+}$and $\mathrm{G} 4 \cdot \mathrm{K}^{+}$gels (Fig. 2 and Table 1). These results are corroborated by the DFT optimized structures of GB diesters and GIAO calculations of ${ }^{11} \mathrm{~B}$ isotropic chemical shifts corresponding to cis and trans isomers of borate diesters (ESI, $\dagger$ Fig. S3). A linear correlation is observed between experimental ${ }^{11} \mathrm{~B}$ isotropic chemical shifts (shown in Table 1) and DFT-calculated ${ }^{11} \mathrm{~B}$ isotropic absolute shielding (ESI, $\dagger$ Fig. S4). These ${ }^{11} \mathrm{~B}$ NMR parameters are expected to be influenced by the changes in the boron environments upon the

Table $1 \quad \delta_{\text {iso }}^{\mathrm{CS}}$ and $P_{\mathrm{Q}}$ values ${ }^{\mathrm{a}}$ of ${ }^{11} \mathrm{~B}$ signals extracted from the plots presented in Fig. 2

\begin{tabular}{|c|c|c|c|c|c|c|}
\hline $\mathrm{G} 4 \cdot \mathrm{M}^{+}$borate gels & Boron site & \multicolumn{3}{|c|}{${ }^{11}$ B NMR shifts (ppm) } & $P_{\mathrm{Q}}(\mathrm{MHz})$ & $\delta_{\text {iso }}^{\mathrm{CS}}(\mathrm{ppm})$ \\
\hline \multirow[t]{2}{*}{$\mathrm{G} 4 \cdot \mathrm{Na}^{+}$gel } & Monoester & 6.9 & 7.1 & 7.3 & 0.77 & 7.5 \\
\hline & Diester (trans) & 12.3 & 12.4 & 12.9 & 0.99 & 13.2 \\
\hline \multirow[t]{2}{*}{$\mathrm{G} 4 \cdot \mathrm{K}^{+}$gel } & Monoester & 6.9 & 7.2 & 7.4 & 0.85 & 7.7 \\
\hline & Diester (cis) & 11.0 & 11.2 & 11.6 & 0.92 & 11.8 \\
\hline
\end{tabular}

${ }^{a}$ Errors on the $P_{\mathrm{Q}}$ and $\delta_{\text {iso }}^{\mathrm{CS}}(\mathrm{ppm})$ are estimated as $\pm 0.01 \mathrm{MHz}$ and $0.1 \mathrm{ppm}$, respectively. The values are calculated by the procedure given in the ESI (Section S2). 
addition of small molecules, as will be studied in the next section. Overall, the MAS NMR studies described above provide us with an excellent method to elucidate the local structures of various $\mathrm{G} 4 \cdot \mathrm{M}^{+}$borate species (G4-network associated $v s$. solvent associated) by analyzing the chemicals shifts of both the templating $\mathrm{M}^{+}$cation and the borate diester as an integral cross-linker in stabilizing these hydrogels. Moreover, as described in the next sections, these multinuclear NMR techniques provide direct insight into the influence that small molecules may have on the structure and properties of the $\mathrm{G} 4 \cdot \mathrm{M}^{+}$borate gels.

\section{The impact of cationic methylene blue (MB) uptake on G. $\mathrm{K}^{+}$gel}

The cationic and planar dye, methylene blue (MB), is well known to bind to G-quadruplex DNA fibrils. ${ }^{54-57}$ We have previously studied the physical absorption of MB by these anionic GB gels, using both UV-Vis spectroscopy and ${ }^{11} \mathrm{~B}$ NMR spectroscopy. ${ }^{21,22}$ In particular, we found that $\mathrm{G} 4 \cdot \mathrm{K}^{+}$gels $(72 \mathrm{mM}$ in $\mathrm{G})$ were able to quantitatively absorb $12.5 \mu \mathrm{M} \mathrm{MB}$ after soaking the hydrogel in a $\mathrm{KCl}$ solution of the dye for $24 \mathrm{~h}$, as determined by UV-Vis spectroscopy. ${ }^{21}$ Importantly, these low $\mu \mathrm{M}$ concentrations of cationic dyes, including $\mathrm{MB}$, act to strengthen the $\mathrm{G} 4 \cdot \mathrm{Li}^{+}$gels, as reflected in the increased storage modulus $\left(G^{\prime}\right)$ of the $\mathrm{Li}^{+} \mathrm{GB}$ hydrogel in the presence of the dyes. ${ }^{58}$

To gain further insight into the impact of absorption of $\mathrm{MB}$ on the structure and stability of the GB gels, high-resolution ${ }^{1} \mathrm{H}$ and ${ }^{11} \mathrm{~B}$ MAS NMR spectra of G4. $\mathrm{K}^{+}$gels (Fig. 3 ) were compared before and after the incorporation of MB into the gel. The ${ }^{1} \mathrm{H}$ signals at 7.7, 6.8 and $6.2 \mathrm{ppm}$ that correspond to aromatic protons in $\mathrm{MB}$ molecules in $\mathrm{GB}$ gels are displaced to lower chemical shifts as compared to the analogous ${ }^{1} \mathrm{H}$ chemical shifts of $0.1 \mathrm{mM} \mathrm{MB}$ in $\mathrm{D}_{2} \mathrm{O}(7.4,7.1$ and $6.9 \mathrm{ppm}){ }^{59}$ These upfield shifts associated with ${ }^{1} \mathrm{H}$ signals of $\mathrm{MB}$ in gels (i.e., $\Delta \delta=0.3,0.3$ and $0.7 \mathrm{ppm}$ for the signals at 7.7, 6.8 and $6.2 \mathrm{ppm}$, respectively) can be attributed to the $\pi-\pi$ stacking and $\mathrm{CH}-\pi$ interactions that occur between $\mathrm{MB}$ and $\mathrm{G} 4$ fibrils. In addition, various binding interactions, such as end stacking, side stacking and parallel stacking of MB molecules to G4-rich DNA, have been previously proposed, ${ }^{55}$ and those same types of interactions may be relevant here in the context of MB binding to the $\mathrm{G} 4 \cdot \mathrm{K}^{+}$gels. Also, a priori, ionic interactions between cationic $\mathrm{MB}$ and borate anions in the $\mathrm{G} 4 \cdot \mathrm{K}^{+}$borate gels are certainly important.

In the ${ }^{1} \mathrm{H}$ NMR spectrum of a sample that had $3 \mathrm{mM}$ MB added to $\mathrm{G} 4 \cdot \mathrm{K}^{+}$gels $(72 \mathrm{mM}$ in $\mathrm{G})$, relatively broad ${ }^{1} \mathrm{H}$ signals (6.2, 6.8 and $7.6 \mathrm{ppm})$ are observed for the aromatic protons in $\mathrm{MB}$, indicating that $\mathrm{MB}$ is embedded in the gel phase. As illustrated in Fig. 3a, a vial inversion test showed that the $\mathrm{G} 4 \cdot \mathrm{K}^{+}$gel remained self-standing in the presence of $3 \mathrm{mM} \mathrm{MB}$. In contrast to the broad MB signals for this sample, narrow ${ }^{1} \mathrm{H}$ signals at $5.8 \mathrm{ppm}\left(\mathrm{H}^{\prime}\right)$ and $7.8 \mathrm{ppm}(\mathrm{H} 8)$ are observed for the free $\mathrm{G}$ in the solution phase. This data indicates that $\mathrm{MB}$ is sequestered in the gel phase at this concentration. Upon addition of a higher concentration of MB (36 mM) to the gels, a vial inversion test showed a runny solution, indicating that this high concentration of dye had triggered a gel-to-sol transition. (a) G4・K+ hydrogel

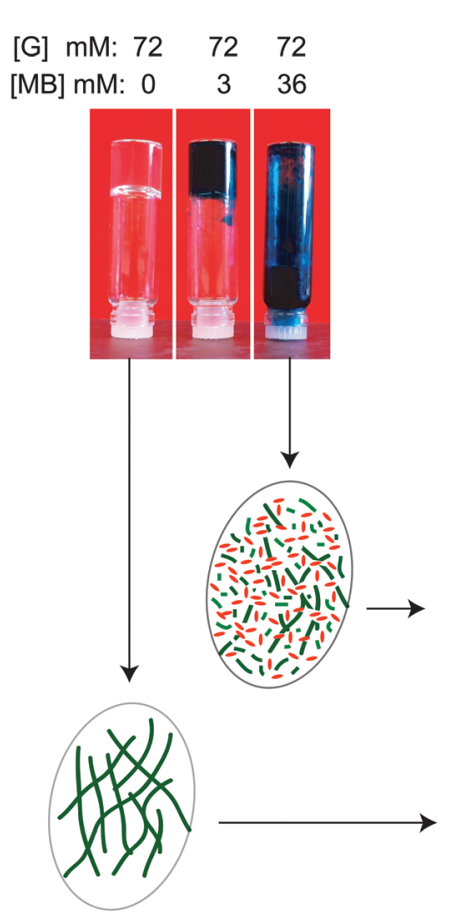

(b)

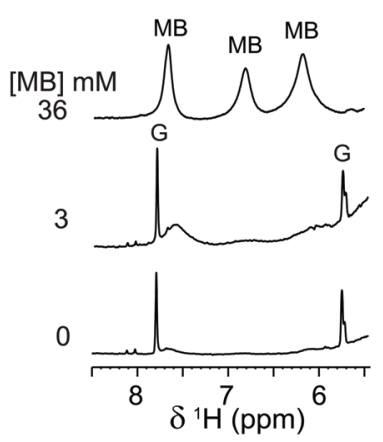

(c)

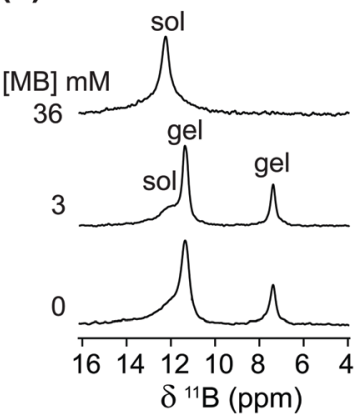

Fig. 3 (a) Photographs of $72 \mathrm{mM} \mathrm{G4} \cdot \mathrm{M}^{+}$borate hydrogels taken before and after the incorporation of $3 \mathrm{mM}$ and $36 \mathrm{mM}$ of $\mathrm{MB}$, accompanied by $1 \mathrm{D}$ (b) ${ }^{1} \mathrm{H}$ and (c) ${ }^{11} \mathrm{~B}$ (20 T, $5 \mathrm{kHz}$ MAS) NMR spectra of $\mathrm{G} 4 \cdot \mathrm{K}^{+}$borate gels shown in the vials (similar ${ }^{11} \mathrm{~B}$ MAS NMR spectra acquired at $11.7 \mathrm{~T}$ are presented in ref. 21). Inset figures in ovals represent schematics of G4 fibrils before and after the addition of methylene blue. Sol and gel ${ }^{11} \mathrm{~B}$ signals correspond to borate mono- and diesters in a solution-like environment and in the G4 network, respectively.

Consistent with this phase transition, the broad ${ }^{1} \mathrm{H}$ NMR signals for MB become much narrower and clearly distinguishable (upper spectrum of Fig. 3b). Under these conditions, the G4 fibrils that make up the gel phase are disrupted and the cationic MB molecules are anticipated to be distributed in the vicinities of monomeric GB species.

To investigate whether the uptake of MB influences the local boron chemical environments in the $\mathrm{G} 4 \cdot \mathrm{K}^{+}$gels, we compared the isotropic ${ }^{11} \mathrm{~B}$ chemical shifts and quadrupolar interactions by analyzing ${ }^{11} \mathrm{~B}$ NMR spectra acquired at different magnetic fields. In particular, the quadrupolar interactions are expected to be sensitive to the gel-to-sol transition. For example, Wallace et al. have exploited ${ }^{2} \mathrm{H}$ and ${ }^{14} \mathrm{~N}$ residual quadrupolar couplings (RQC) to understand the self-assembly process of a dipeptide gelator. ${ }^{60,61}$ The ${ }^{11} \mathrm{~B}$ MAS NMR spectra acquired before and after the addition of MB exhibited different spectral features for different sol-gel ratios, depending on the concentration of added MB. Although similar ${ }^{11} \mathrm{~B}$ NMR titrations, monitoring ${ }^{11} \mathrm{~B}$ chemical shifts as a function of concentration of added MB, have previously been presented in the ESI of ref. 21, the emphasis in this current study is placed on understanding whether or not the gel-to-sol transition causes significant differences in the local chemical environments of the borate anions, particularly, in the presence of excess of MB (36 mM). 
Table $2{ }^{11} \mathrm{~B} N M R \delta_{\text {iso }}^{\mathrm{CS}}$ and $P_{\mathrm{Q}}$ parameters ${ }^{a}$ for the $\mathrm{G} 4 \cdot \mathrm{K}^{+}$gels before and after MB uptake

\begin{tabular}{|c|c|c|c|c|c|}
\hline \multirow{2}{*}{$\begin{array}{l}{\left[\mathrm{G} 4 \cdot \mathrm{K}^{+} \mathrm{gel}\right]:} \\
{[\mathrm{MB}] \mathrm{mM}}\end{array}$} & \multirow[b]{2}{*}{ Boron site } & \multicolumn{2}{|c|}{${ }^{11} \mathrm{~B}$ shifts (ppm) } & \multirow[b]{2}{*}{$P_{\mathrm{Q}}(\mathrm{MHz})$} & \multirow[b]{2}{*}{$\delta_{\text {iso }}^{\mathrm{CS}}(\mathrm{ppm})$} \\
\hline & & $11.7 \mathrm{~T}$ & $20 \mathrm{~T}$ & & \\
\hline \multirow[t]{3}{*}{$72: 0$} & Monoester & 6.9 & 7.4 & 0.85 & 7.7 \\
\hline & Diester (cis) & 11.0 & 11.6 & 0.92 & 11.8 \\
\hline & Diester (trans) & 11.7 & 12.2 & 0.89 & 12.4 \\
\hline \multirow[t]{3}{*}{$72: 3$} & Monoester & 7.0 & 7.4 & 0.89 & 7.6 \\
\hline & Diester (cis) & 11.0 & 11.6 & 0.92 & 11.9 \\
\hline & Diester (trans) & 11.7 & 12.2 & 0.89 & 12.4 \\
\hline \multirow[t]{3}{*}{$72: 36$} & Monoester & 7.0 & 7.5 & 0.91 & 7.8 \\
\hline & Diester (cis) & 11.2 & 12.2 & 1.22 & 12.7 \\
\hline & Diester (trans) & 11.8 & 12.5 & 1.05 & 12.9 \\
\hline
\end{tabular}

${ }^{a}$ Errors on the $P_{\mathrm{Q}}$ and $\delta_{\text {iso }}^{\mathrm{CS}}(\mathrm{ppm})$ are estimated as $\pm 0.01 \mathrm{MHz}$ and $0.1 \mathrm{ppm}$, respectively. The values are calculated by the procedure given in the ESI (Section S2).

It is noteworthy that the ${ }^{11} \mathrm{~B}$ signal intensities associated with the GB monoester (7.4 ppm) and the cis isomer of GB diester (11.6 ppm) are reduced upon the addition of $36 \mathrm{mM} \mathrm{MB}$, which indicates that both GB mono- and diesters (cis isomer) enhance the gelation of G4 borate esters in the presence of $\mathrm{K}^{+}$ ions. In contrast, the ${ }^{11} \mathrm{~B}$ signal intensity corresponding to the trans isomer of the GB diester (12.4 ppm) increased as a function of the increased concentration of $\mathrm{MB}$, which suggests that the trans GB diester plays a subtle role in the gelation process. ${ }^{18}$ The isotropic chemical shift $\delta_{\text {iso }}^{\mathrm{CS}}$ and quadrupolar product $P_{\mathrm{Q}}$ were calculated from the ${ }^{11} \mathrm{~B}$ NMR data acquired at two different magnetic field strengths, $11.7 \mathrm{~T}$ and $20 \mathrm{~T}$ (Table 2).

The gel-to-sol transition results in subtle, but detectable, changes in the $P_{\mathrm{Q}}$ values of the diester gel signals in the range between 0.85 and $1.2 \mathrm{MHz}$. While these changes in the $P_{\mathrm{Q}}$ values do not confirm the presence of intermolecular interactions between $\mathrm{MB}$ and $\mathrm{G} 4 \cdot \mathrm{M}^{+}$borate gels, they do show that changes occur in local chemical environments of the borate anions upon a gel-to-sol transition, which is consistent with the ${ }^{1} \mathrm{H}$ NMR studies of MB added $\mathrm{G} 4 \cdot \mathrm{K}^{+}$gels. Together, the visual tip tests and the corresponding ${ }^{1} \mathrm{H}$ and ${ }^{11} \mathrm{~B}$ MAS NMR analyses of the different samples shown in Fig. 3 indicate that addition of excess of MB interrupts the G4 quartet borate esters and intermolecular interactions that stabilize the gel. Clearly, gel-state MAS NMR spectroscopy is a valuable method to gauge the impact of how small molecules, such as MB, can influence the sol-gel transition in these $\mathrm{G} 4 \cdot \mathrm{M}^{+}$borate gels. It is noted that ${ }^{1} \mathrm{H}-{ }^{13} \mathrm{C}$ CP-MAS NMR experiments have previously been applied to characterize xerogels and organic phases integrated into mesoporous silica. ${ }^{26,32}$ However, the low sensitivity of ${ }^{1} \mathrm{H}-\mathrm{X}$ $\left(\mathrm{X}={ }^{13} \mathrm{C},{ }^{15} \mathrm{~N}\right) \mathrm{CP}$-MAS NMR is a bottleneck, for example, ${ }^{13} \mathrm{C}$ spectra of xerogels have been acquired by signal averaging several hours to days depending on the swelling solvent. ${ }^{26}$ In the case of GB hydrogels containing $\sim 2$ wt $\%$ gel network, ${ }^{22}$ carrying out a large number of ${ }^{1} \mathrm{H}-\mathrm{X}\left(\mathrm{X}={ }^{13} \mathrm{C},{ }^{15} \mathrm{~N}\right)$ CP-MAS NMR titration experiments as a function of increasing concentration of guest molecules (Fig. 3) is anticipated to be less suitable, particularly, when dilute concentrations of guest molecules ( $\leq 0.1$ equiv. of gelator molecules) are involved.

\section{Addition of nucleobases into $\mathbf{G} \cdot \mathrm{K}^{+}$borate hydrogels}

To explore the uptake of neutral guest molecules, we next studied the incorporation of nucleosides into $\mathrm{G} 4 \cdot \mathrm{M}^{+}$borate gels. Indeed, nucleobases such as adenine and closely related heterocycles with antiviral action show relatively poor solubility in water $(\sim 7 \mathrm{mM})$ and water/additive binary solutions $(\sim 20 \mathrm{mM}$ adenine in the presence of $1 \mathrm{M}$ arginine as an additive), ${ }^{62-64}$ which poses a challenge for their therapeutic applications. It has been reported that added sugars including ribose ${ }^{65}$ and especially galactose and lactose ${ }^{66}$ can enhance the solubility of adenine in water by using $\mathrm{CH}-\pi$ interactions ${ }^{67}$ that disrupt the base stacking processes that lead to adenine aggregation. ${ }^{68,69}$ In addition, supramolecular chemistry approaches, ${ }^{70}$ including using Rebek/Kemp triacid receptors, ${ }^{71}$ cyclodextrins $^{72,73}$ and biodegradable polymers ${ }^{74}$ have been exploited to increase the water solubility of adenine and enhance its transport across biological membranes.

To examine the nucleobase solubility in GB gels, we employed adenine concentrations over $30 \mathrm{mM}$, which is well beyond the limit of its solubility in water $(\sim 7 \mathrm{mM}) \cdot{ }^{62-64}$ While $32 \mathrm{mM}$ adenine precipitates in $\mathrm{H}_{2} \mathrm{O}$ (Fig. 4, inset photograph), the same concentration of adenine added to a $72 \mathrm{mM} \mathrm{G} 4 \cdot \mathrm{K}^{+}$
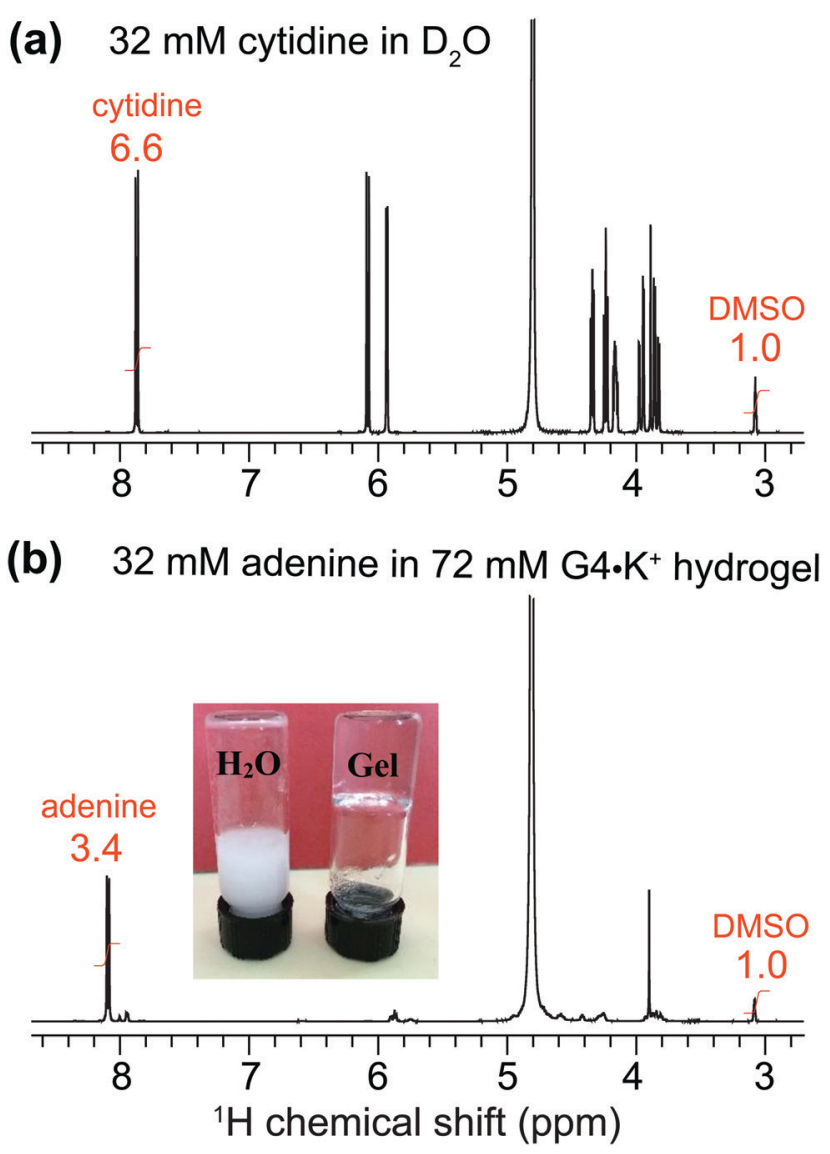

Fig. 4 Solution-state $1 \mathrm{D}^{1} \mathrm{H}(600 \mathrm{MHz})$ NMR spectrum of (a) $32 \mathrm{mM}$ of cytidine dissolved in $\mathrm{D}_{2} \mathrm{O}$ using DMSO proton signals (at $3.09 \mathrm{ppm}$, integral of 1.0) as an internal calibration standard, and (b) of $32 \mathrm{mM}$ adenine incorporated into a $\mathrm{G} 4 \cdot \mathrm{K}^{+}$gel. The inset image in (b) depicts the dissolution of $32 \mathrm{mM}$ of adenine in $\mathrm{H}_{2} \mathrm{O}$ (left) and in $72 \mathrm{mM} \mathrm{G4} \cdot \mathrm{K}^{+}$borate gel (right). 
borate gel (right vial) shows no precipitation and the hydrogel remains transparent over several days. A solution state ${ }^{1} \mathrm{H}$ NMR spectrum of this $\mathrm{G} 4 \cdot \mathrm{K}^{+}$borate gel containing adenine indicates that the majority of the nucleobase $(\sim 30.9 \mathrm{mM})$ remains in the solution-like environment (bottom), i.e., adenine molecules or their aggregates freely diffuse. In comparison to the MB incorporated $\mathrm{G} 4 \cdot \mathrm{K}^{+}$gel (Fig. 3b), relatively narrow signals are observed in the ${ }^{1} \mathrm{H}$ NMR spectrum of adenine added $\mathrm{G} 4 \cdot \mathrm{K}^{+}$ gels (Fig. 4b), which is consistent with the dissolution of adenine in the solution phase rather than being closely associated with the network that makes up $\mathrm{G} 4 \cdot \mathrm{K}^{+}$gels. To estimate the adenine content in the solution phase of the $\mathrm{G} 4 \cdot \mathrm{K}^{+}$gel, we carried out a quantitative ${ }^{1} \mathrm{H}$ NMR analysis. A known concentration of cytidine ( $32 \mathrm{mM}$ ) was dissolved in $\mathrm{D}_{2} \mathrm{O}$ with a DMSO internal standard (Fig. 4a). The ${ }^{1} \mathrm{H}$ signal integral of two cytidine protons centered at $\delta=7.93 \mathrm{ppm}$ was 6.6 with respect to an integral of 1.0 corresponding to the ${ }^{1} \mathrm{H}$ signals of DMSO $(\delta=3.09 \mathrm{ppm})$. Similarly, in a ${ }^{1} \mathrm{H}$ NMR spectrum shown in Fig. $4 \mathrm{~b}$, the signal centered at $\delta=\sim 8.1 \mathrm{ppm}$ is representative of adenine's aromatic proton integrated to 3.4 (relative to an integral of 1.0 corresponding to the same ${ }^{1} \mathrm{H}$ signals of DMSO), indicating that $\sim 31 \mathrm{mM}$ of the adenine was in the solution phase. This suggests that the adenine was introduced into the pores of the gel matrix rather than being closely associated with the boron containing gel. Such minute quantities of DMSO likely do not disrupt the hydrogen bonding networks in hydrogels, yet the gel stability is maintained as confirmed by a vial inversion test. The enhanced adenine solubility in GB gels could be related to several mechanisms and hypotheses proposed in the previous studies; for example, alcohol/water or glycol/water binary mixtures enhance the adenine solubility, ${ }^{62,64}$ the presence of an amino acid additive such as arginine improves the solubility of adenine in water, ${ }^{63}$ and also the presence of dideoxynucleosides augments adenine solubility in water. ${ }^{75}$ In particular, it has been hypothesized that the hydrogen bonding interactions between polar OH groups associated with alcohols and adenine moieties dominate as compared to the base stacking of these latter molecules. ${ }^{62,64}$ While such noncovalent interactions are anticipated to be relevant in GB gels, the roles of enhanced polarity of the solution phase (due to the borate buffer) of GB gels in enhancing the adenine solubility cannot be ruled out.

\section{Uptake of nucleobases by $\mathbf{G} 4 \cdot \mathrm{Na}^{+}$borate gels}

The enhanced solubility of adenine in $\mathrm{G} 4 \cdot \mathrm{K}^{+}$gel prompted us to investigate the solubility of different nucleobases in $\mathrm{G} 4 \cdot \mathrm{Na}^{+}$gel, which did not pose the same cardiotoxicity risks as gels containing potassium ions for one particular adenine delivery application we were envisaging. Hence, in order to examine the solubility of different nucleobases in $\mathrm{G} 4 \cdot \mathrm{Na}^{+}$borate gel, hot saturated solutions of the $\mathrm{G} 4 \cdot \mathrm{Na}^{+}$borate gels (72 $\mathrm{mM} \mathrm{G}$ ) were added to the vials containing known concentrations of adenine, guanine, cytosine and 1-methylthymine. The resultant solutions were homogenized by mild agitation and allowed to settle at room temperature. Hydrogel stability was determined by vial inversion tests performed after an hour and after a day (ESI, $\uparrow$ Fig. S5-S7). The nucleobase solubility was monitored over a week. These visual observations show that the addition of a relatively low concentration of nucleobases does not influence the gelation properties, however, increased heterocycle loading reduces the gelation properties of the $\mathrm{G} 4 \cdot \mathrm{Na}^{+}$borate gels (ESI, $\dagger$ Tables S2-S4). The nucleobase solubility is enhanced for adenine, cytosine and 1-methylthymine, although the effect is relatively smaller for cytosine, where there is a tendency for precipitation over time. Notably, transparent gels are observed upon the addition of adenine and 1-methylthymine, meaning that these molecules are situated in the solution phase of the hydrogel. While guanine is notoriously insoluble in water (a cloudy solution was observed when $1 \mathrm{mg}$ of guanine was added to $250 \mathrm{~mL}$ water), we found that it can be brought into solution at a low concentration of $0.054 \mathrm{mM}$ by the gels, which was not studied any further.

Adenine exhibited remarkable solubility in $\mathrm{G} 4 \cdot \mathrm{Na}^{+}$hydrogels. After adding $64 \mathrm{mM}$ adenine, the $\mathrm{G} 4 \cdot \mathrm{Na}^{+}$gel remained stable and clear. The absorption process of adenine is monitored by carrying out solution-state ${ }^{1} \mathrm{H}$ NMR and gel-state ${ }^{11} \mathrm{~B}$ and ${ }^{23} \mathrm{Na}$ MAS NMR titration experiments (Fig. 5). The stability and integrity of $\mathrm{G} 4 \cdot \mathrm{Na}^{+}$gel is reflected in the ${ }^{1} \mathrm{H}$ and ${ }^{11} \mathrm{~B}$ NMR spectra, although increased ${ }^{1} \mathrm{H}$ signal $(\delta=7.8 \mathrm{ppm})$ intensities for adenine confirm that there is a rise in the concentration of (a)

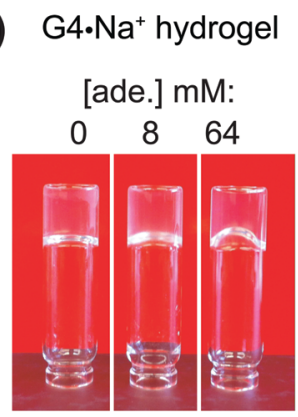

(c)
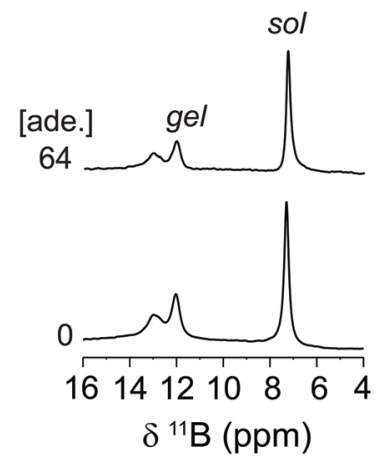

(b)

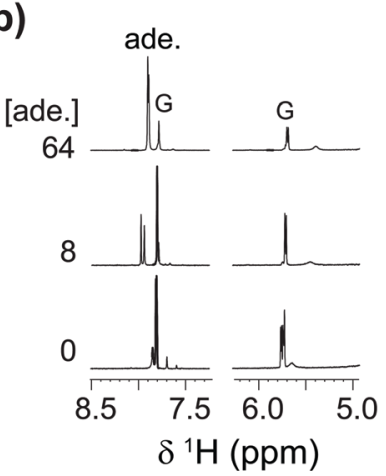

(d)

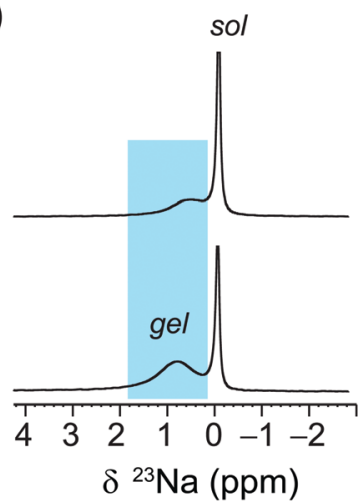

Fig. 5 (a) Photographs of $72 \mathrm{mM} \mathrm{G} 4 \cdot \mathrm{Na}^{+}$borate hydrogels taken before and after the incorporation of $8 \mathrm{mM}$ and $64 \mathrm{mM}$ of adenine. (b) ${ }^{1} \mathrm{H}$ (9.4 T, $400 \mathrm{MHz}$ ), (c) ${ }^{11} \mathrm{~B}(20 \mathrm{~T}, 5 \mathrm{kHz} \mathrm{MAS})$ and (d) ${ }^{23} \mathrm{Na}$ (20 T, $5 \mathrm{kHz}$ MAS) NMR spectra of G4. $\mathrm{Na}^{+}$borate gels shown in the inverted vials in (a). Sol and gel signals correspond to free cations or molecules in a solution-like environment and in the G4 network, respectively. 
adenine in the gel. Nevertheless, the lineshape fitting analyses of the gel-state ${ }^{23} \mathrm{Na}$ MAS NMR spectra showed different distributions of $\mathrm{Na}^{+}$ions in solution and gel regions before and after the addition of adenine. The distribution of $\mathrm{Na}^{+}$ions content in the adenine added gel is $42 \pm 4 \%$ (cations associated with the G4 gel network) and $58 \pm 4 \%$ (free cations in solution) respectively, as compared to $69 \pm 4 \%$ (gel network) and $41 \pm$ $4 \%$ (solution) in the pristine $\mathrm{G} 4 \cdot \mathrm{Na}^{+}$gel. In addition, the ${ }^{23} \mathrm{Na}$ signal associated with the gel network is displaced to $0.5 \mathrm{ppm}$, as compared to $0.8 \mathrm{ppm}(\Delta \delta=0.3 \mathrm{ppm})$ for the same ${ }^{23} \mathrm{Na}$ signal in the pristine gel. These results and analyses confirm that the majority of adenine molecules are located in the pores of the solution phase, and dilute concentrations of adenine molecules are embedded into the gel framework. The impact of increased polarity due to the presence of alkali metal borate salts in the solution phase of the hydrogel on enhanced solubility of adenine cannot be ruled out. The addition of higher concentrations of nucleobases, specifically above $72 \mathrm{mM}$, reduce the integrity of gels with there being a trend of precipitating out the solute over time.

Further insights into the solubility of nucleosides into $\mathrm{G} 4 \cdot \mathrm{Na}^{+}$borate gels were obtained by monitoring the absorption process of cytosine (Fig. 6). The ${ }^{1} \mathrm{H}$ solution-state NMR titration

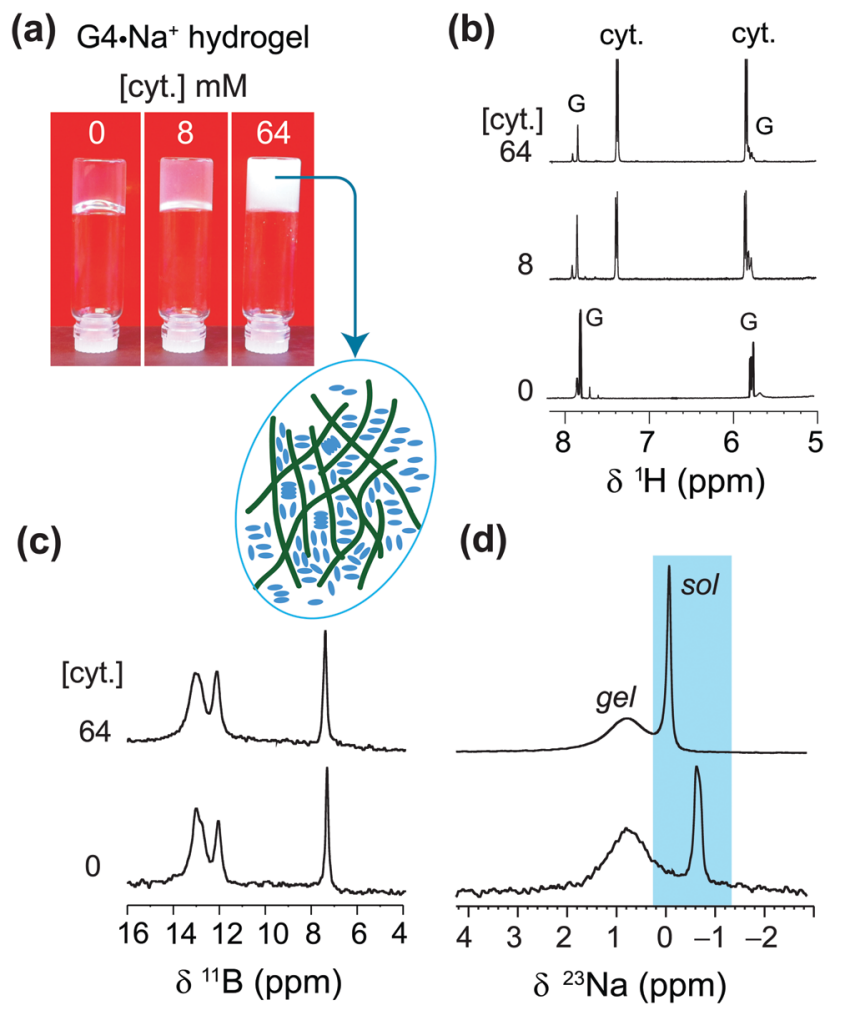

Fig. 6 (a) Photographs of $72 \mathrm{mM} \mathrm{G} 4 \cdot \mathrm{Na}^{+}$borate hydrogels taken before and after the incorporation of $8 \mathrm{mM}$ and $64 \mathrm{mM}$ of cytosine, accompanied by one-pulse (b) ${ }^{1} \mathrm{H}(9.4 \mathrm{~T}, 400 \mathrm{MHz}),(\mathrm{c}){ }^{11} \mathrm{~B}(20 \mathrm{~T}, 5 \mathrm{kHz} \mathrm{MAS})$ and (d) ${ }^{23} \mathrm{Na}$ (20 T, $5 \mathrm{kHz}$ MAS) NMR spectra of $\mathrm{G} \cdot \mathrm{Na}^{+}$borate gels shown in the inverted vials (a). The inset figure depicts that how cytosine molecules are aggregated in the pores of the gel framework, which leads to precipitation. Sol and gel signals correspond to free ions or molecules in a solution-like environment and in the G4 network, respectively. showed increased cytosine concentration in the solution phase of the gel framework (Fig. 6b), as revealed by the narrow ${ }^{1} \mathrm{H}$ signals at 5.8 and $7.4 \mathrm{ppm}$. As expected, ${ }^{11} \mathrm{~B}$ MAS NMR spectra recorded before and after the incorporation of cytosine showed no significant changes in the spectral patterns (Fig. 6c). These results are corroborated by gel-state ${ }^{23} \mathrm{Na}$ MAS NMR spectroscopy, which showed displacement of the ${ }^{23} \mathrm{Na}$ chemical shift $(\Delta \delta=-0.7 \mathrm{ppm})$ accompanied by changes in the local environments of $\mathrm{Na}^{+}$ions in the solution phase (Fig. 6d). The signal integrals measured from the lineshape analyses of ${ }^{23} \mathrm{Na}$ MAS NMR spectra confirmed that the distributions of the $\mathrm{Na}^{+}$ions in solution $(69 \pm 4 \%)$ and $\mathrm{G} 4$ gel network (31 $\pm 4 \%$ ) before and after the addition of cytosine are the same. From these results and analysis, it could be inferred that cytosine moieties are largely confined within the pores of the gel network and the addition of higher concentrations of over $64 \mathrm{mM}$ cytosine leads to precipitation, which reduces the gel stability. The solubility of 1-methylthymine was however significantly improved from $50 \mathrm{mM}$ to at least $70 \mathrm{mM}$ in $\mathrm{G} 4 \cdot \mathrm{Na}^{+}$borate gel (ESI, $\dagger$ Table S4). All of these findings reveal that these $\mathrm{G} 4 \cdot \mathrm{K}^{+}$ and $\mathrm{G} 4 \cdot \mathrm{Na}^{+}$borate gels have the potential to adsorb small molecule drugs in the range between 0.05 and 0.5 equiv. with minimal disruption to the G-quartet gel framework.

\section{Conclusions}

Insights into the roles of alkali cations and borate anions in the gelation of G4 borate hydrogels are obtained by multinuclear $\left({ }^{7} \mathrm{Li},{ }^{11} \mathrm{~B},{ }^{23} \mathrm{Na},{ }^{39} \mathrm{~K}\right.$ and $\left.{ }^{133} \mathrm{Cs}\right)$ MAS NMR spectroscopy in conjunction with DFT modelling. A comparison of 1D MAS NMR spectra of alkali metals enabled free cations versus G-quartet associated alkali metal cations to be distinguished and quantified, which reveals that the $\mathrm{K}^{+}$and $\mathrm{Na}^{+}$cations stabilize the borate gel more than gels using $\mathrm{Li}^{+}$and $\mathrm{Cs}^{+}$ions. In addition, ${ }^{11} \mathrm{~B}$ isotropic chemical shifts and quadrupole interactions were determined by analyzing $1 \mathrm{D}{ }^{11} \mathrm{~B}$ MAS NMR spectra acquired at different magnetic fields, $11.7 \mathrm{~T}, 14.1 \mathrm{~T}$ and $20 \mathrm{~T}$, enabling the different local bonding environments of borate anions in the G4 network and in solution to be distinguished and identified. A combined ${ }^{11} \mathrm{~B}$ MAS NMR and DFT modelling study reveals that the GB cis diesters promote the gelation of G-quartets.

Multinuclear MAS NMR is employed to characterize molecular-level interactions between biologically relevant small heterocyclic molecules and $\mathrm{G} 4 \cdot \mathrm{M}^{+}\left(\mathrm{M}^{+}=\mathrm{K}^{+}, \mathrm{Na}^{+}\right)$hydrogels. While the uptake of up to 0.3 equivalent of cationic methylene blue (i.e., 0.3 equiv. of $\mathrm{MB}$ per equiv. of $\mathrm{G}$ ) yields stable and intact $\mathrm{G} 4 \cdot \mathrm{K}^{+}$borate gel, the $\mathrm{MB}$ concentrations over 0.3 equiv. triggered a gel-to-sol transition caused by the disruption of G4-fibrils that make the gel. The sol-gel transition of $\mathrm{MB}$ loaded $\mathrm{G} 4 \cdot \mathrm{K}^{+}$gel, monitored by ex situ ${ }^{1} \mathrm{H}$ and ${ }^{11} \mathrm{~B}$ MAS NMR titration experiments, revealed changes in the isotropic ${ }^{1} \mathrm{H}$ and ${ }^{11} \mathrm{~B}$ chemical shifts. These changes are corroborated by the vial inversions, which confirm the gel-to-sol transition. The uptake processes of different heterocyclic compounds into $\mathrm{G} 4 \cdot \mathrm{K}^{+}$and 
$\mathrm{G} 4 \cdot \mathrm{Na}^{+}$borate gels were studied and compared. Adenine is readily soluble in $\mathrm{G} 4 \cdot \mathrm{Na}^{+}$borate gel with adenine concentrations of up to $72 \mathrm{mM}$, i.e., one equivalent per $\mathrm{G}$ ( $72 \mathrm{mM})$, although smaller aggregates form when the adenine concentrations exceed $64 \mathrm{mM}$. Cytosine solubility is enhanced to a more modest $32 \mathrm{mM}$ by the borate gel. The solubility of a pyrimidine, 1-methylthymine, was however significantly improved from $50 \mathrm{mM}$ to at least $70 \mathrm{mM}$ in $\mathrm{G} 4 \cdot \mathrm{Na}^{+}$borate gel. The uptake process was monitored by solutionstate ${ }^{1} \mathrm{H}$ and gel-state ${ }^{11} \mathrm{~B}$ and ${ }^{23} \mathrm{Na}$ NMR titration experiments. The ${ }^{1} \mathrm{H}$ NMR results suggest that these heterocyclic nucleobases are incorporated into the solution phase, which are corroborated by the ${ }^{23} \mathrm{Na}$ MAS NMR results.

To summarize, G4-quartet borate gels provide a useful material into which small molecule drugs such as cationic dyes and heterocyclic compounds can be taken up, which we are exploring further as potential delivery agents. Gel-state MAS NMR spectroscopy provides valuable atomic-level insight into the sol-gel compositions and structures, and differentiate local arrangements of order and disorder of as-synthesized gels as well as guest molecules absorbed into the functional gels, which can be correlated and complemented by morphological features and long-range order characterized by conventional bulk techniques such as X-ray scattering and electron microscopy. Although multinuclear 1D MAS NMR is a powerful probe to characterize the GB gels and specific intermolecular interactions between guest molecules and gelator molecules, it can be envisaged that $2 \mathrm{D}{ }^{1} \mathrm{H}-{ }^{1} \mathrm{H}$ and ${ }^{1} \mathrm{H}-\mathrm{X}\left(\mathrm{X}={ }^{13} \mathrm{C},{ }^{11} \mathrm{~B},{ }^{23} \mathrm{Na}\right.$, etc.) correlation NMR spectroscopy in conjunction with other complementary techniques and sophisticated modelling approaches may further help in the determination of packing interactions and the three-dimensional structure of the gel network. However, the complex compositions and structures of GB hydrogels present challenges given the sensitivity and resolution of such MAS NMR techniques, for example, when small quantities of structurally similar guest molecules are added to the hydrogels (i.e., guest molecule concentration lower than 0.1 equiv. of gelator molecule). In this respect, studies of the lowest limit of detection of small molecule guests in GB hydrogels using multinuclear MAS NMR techniques are yet to be examined and compared, but could be a focus of future investigations.

\section{Conflicts of interest}

There are no conflicts to declare.

\section{Acknowledgements}

We acknowledge funding from EPSRC (EP/K003674/1). The UK $850 \mathrm{MHz}$ solid-state NMR Facility used in this research was funded by EPSRC and BBSRC, as well as the University of Warwick including via part funding through Birmingham Science City Advanced Materials Projects 1 and 2 supported by Advantage West Midlands (AWM) and the European Regional Development Fund (ERDF); the Facility Manager, Dr Dinu
Iuga, is thanked for experimental assistance. B. P. T. thanks Bruker and the University of Warwick for PhD funding as part of the Warwick Centre for Doctoral Training in Analytical Science. T. S. R. thanks the Warwick Undergraduate Research Scholarship Scheme for funding. S. M. K. and J. Z. thank the Study Abroad Program 2014, NTU Singapore and Xiamen University, China respectively. J. T. D. thanks the Office of Basic Energy Sciences, U.S. Dept. of Energy (DEFG02-98ER14888) for financial support and the NSF (NSF-1726058) for NMR funding. We thank Prof. Sharon E. Ashbrook for insightful discussions on the calculation of quadrupolar parameters. The experimental data for this study are provided as a supporting dataset from WRAP, the Warwick Research Archive Portal at http:// wrap.warwick.ac.uk/141042/.

\section{References}

1 B. O. Okesola and D. K. Smith, Chem. Soc. Rev., 2016, 45, 4226-4251.

2 J.-F. Lutz, J.-M. Lehn, E. W. Meijer and K. Matyjaszewski, Nat. Rev. Mater., 2016, 1, 16024.

3 R. Freeman, M. Han, Z. Álvarez, J. A. Lewis, J. R. Wester, N. Stephanopoulos, M. T. McClendon, C. Lynsky, J. M. Godbe, H. Sangji, E. Luijten and S. I. Stupp, Science, 2018, 362, 808.

4 O. P. Lee, A. T. Yiu, P. M. Beaujuge, C. H. Woo, T. W. Holcombe, J. E. Millstone, J. D. Douglas, M. S. Chen and J. M. J. Fréchet, Adv. Mater., 2011, 23, 5359-5363.

5 A. M. Vibhute, V. Muvvala and K. M. Sureshan, Angew. Chem., Int. Ed., 2016, 55, 7782-7785.

6 R. G. Weiss, J. Am. Chem. Soc., 2014, 136, 7519-7530.

7 X. Shen, J. L. Shamshina, P. Berton, G. Gurau and R. D. Rogers, Green Chem., 2016, 18, 53-75.

8 X. Du, J. Zhou, J. Shi and B. Xu, Chem. Rev., 2015, 115, 13165-13307.

9 G. M. Peters and J. T. Davis, Chem. Soc. Rev., 2016, 45, 3188-3206.

10 Q. Tang, T. N. Plank, T. Zhu, H. Yu, Z. Ge, Q. Li, L. Li, J. T. Davis and H. Pei, ACS Appl. Mater. Interfaces, 2019, 11, 19743-19750.

11 M. Li, H. Wang, J. Hu, J. Hu, S. Zhang, Z. Yang, Y. Li and Y. Cheng, Chem. Mater., 2019, 31, 7678-7685.

12 J. Li and D. J. Mooney, Nat. Rev. Mater., 2016, 1, 16071.

13 L. Stefan and D. Monchaud, Nat. Rev. Chem., 2019, 3, 650-668.

14 Y. P. Kumar, R. N. Das, O. M. Schütte, C. Steinem and J. Dash, Nat. Protoc., 2016, 11, 1039.

15 J. T. Davis and G. P. Spada, Chem. Soc. Rev., 2007, 36, 296-313. 16 D. González-Rodríguez, J. L. J. van Dongen, M. Lutz, A. L. Spek, A. P. H. J. Schenning and E. W. Meijer, Nat. Chem., 2009, 1, 151-155.

17 Y. Li, Y. Liu, R. Ma, Y. Xu, Y. Zhang, B. Li, Y. An and L. Shi, ACS Appl. Mater. Interfaces, 2017, 9, 13056-13067.

18 S. Pieraccini, M. Campitiello, F. Carducci, J. T. Davis, P. Mariani and S. Masiero, Org. Biomol. Chem., 2019, 17, 2759-2769. 
19 R. Zhong, Q. Tang, S. Wang, H. Zhang, F. Zhang, M. Xiao, T. Man, X. Qu, L. Li, W. Zhang and H. Pei, Adv. Mater., 2018, 30, 1706887.

$20 \mathrm{~J} . \mathrm{Hu}, \mathrm{H}$. Wang, Q. Hu and Y. Cheng, Mater. Chem. Front., 2019, 3, 1323-1327.

21 G. M. Peters, L. P. Skala, T. N. Plank, B. J. Hyman, G. N. Manjunatha Reddy, A. Marsh, S. P. Brown and J. T. Davis, J. Am. Chem. Soc., 2014, 136, 12596-12599.

22 G. M. Peters, L. P. Skala, T. N. Plank, H. Oh, G. N. Manjunatha Reddy, A. Marsh, S. P. Brown, S. R. Raghavan and J. T. Davis, J. Am. Chem. Soc., 2015, 137, 5819-5827.

23 A. Rotaru, G. Pricope, T. N. Plank, L. Clima, E. L. Ursu, M. Pinteala, J. T. Davis and M. Barboiu, Chem. Commun., 2017, 53, 12668-12671.

24 T. N. Plank, L. P. Skala and J. T. Davis, Chem. Commun., 2017, 53, 6235-6238.

25 Molecular Gels: Materials with Self-Assembled Fibrillar Networks, ed. R. G. Weiss and P. Terech, Springer, Dordrecht, 2006.

26 Nonappa, M. Lahtinen, B. Behera, E. Kolehmainen and U. Maitra, Soft Matter, 2010, 6, 1748-1757.

27 V. Noponen, Nonappa, M. Lahtinen, A. Valkonen, H. Salo, E. Kolehmainen and E. Sievänen, Soft Matter, 2010, 6, 3789-3796.

28 Cellulose-Based Superabsorbent Hydrogels, ed. M. Azeera, S. Vaidevi, K. Ruckmani and M. I. H. Mondal, Springer International Publishing, Cham, 2018, pp. 1-24.

29 Nonappa and E. Kolehmainen, Soft Matter, 2016, 12, 6015-6026.

30 Nonappa and E. Kolehmainen, in NMR and MRI of Gels, ed. Y. De Geene, The Royal Society of Chemistry, 2020, pp. 200-227.

31 Y. E. Shapiro, in NMR and MRI of Gels, ed. Y. De Geene, The Royal Society of Chemistry, 2020, pp. 45-88.

32 J. Brus, W. Albrecht, F. Lehmann, J. Geier, J. Czernek, M. Urbanova, L. Kobera and A. Jegorov, Mol. Pharmaceutics, 2017, 14, 2070-2078.

33 B. Escuder, M. Llusar and J. F. Miravet, J. Org. Chem., 2006, 71, 7747-7752.

34 M. R. Hansen, R. Graf and H. W. Spiess, Chem. Rev., 2016, 116, 1272-1308.

35 A. Marchetti, J. Chen, Z. Pang, S. Li, D. Ling, F. Deng and X. Kong, Adv. Mater., 2017, 29, 1605895.

36 M. Siefrid, G. N. M. Reddy, B. F. Chmelka and G. C. Bazan, Nat. Rev. Mater., 2020, DOI: 10.1038/s41578-020-00232-5.

37 G. N. M. Reddy, A. Huqi, D. Iuga, S. Sakurai, A. Marsh, J. T. Davis, S. Masiero and S. P. Brown, Chem. - Eur. J, 2017, 23, 2235.

38 A. L. Webber, S. Masiero, S. Pieraccini, J. C. Burley, A. S. Tatton, D. Iuga, T. N. Pham, G. P. Spada and S. P. Brown, J. Am. Chem. Soc., 2011, 133, 19777-19795.

39 G. N. M. Reddy, M. Malon, A. Marsh, Y. Nishiyama and S. P. Brown, Anal. Chem., 2016, 88, 11412-11419.

40 C. E. Hughes, G. N. M. Reddy, S. Masiero, S. P. Brown, P. A. Williams and K. D. M. Harris, Chem. Sci., 2017, 8, 3971-3979.

41 A. Khitrin and B. M. Fung, J. Chem. Phys., 2000, 112, 2392.
42 J. W. E. Weiss and D. L. Bryce, J. Phys. Chem. A, 2010, 114, 5119-5131.

43 M. J. Frisch, G. W. Trucks, H. B. Schlegel, G. E. Scuseria, M. A. Robb, J. R. Cheeseman, G. Scalmani, V. Barone, G. A. Petersson, H. Nakatsuji, X. Li, M. Caricato, A. V. Marenich, J. Bloino, B. G. Janesko, R. Gomperts, B. Mennucci, H. P. Hratchian, J. V. Ortiz, A. F. Izmaylov, J. L. Sonnenberg, D. Williams-Young, F. Ding, F. Lipparini, F. Egidi, J. Goings, B. Peng, A. Petrone, T. Henderson, D. Ranasinghe, V. G. Zakrzewski, J. Gao, N. Rega, G. Zheng, W. Liang, M. Hada, M. Ehara, K. Toyota, R. Fukuda, J. Hasegawa, M. Ishida, T. Nakajima, Y. Honda, O. Kitao, H. Nakai, T. Vreven, K. Throssell, J. A. Montgomery, Jr., J. E. Peralta, F. Ogliaro, M. J. Bearpark, J. J. Heyd, E. N. Brothers, K. N. Kudin, V. N. Staroverov, T. A. Keith, R. Kobayashi, J. Normand, K. Raghavachari, A. P. Rendell, J. C. Burant, S. S. Iyengar, J. Tomasi, M. Cossi, J. M. Millam, M. Klene, C. Adamo, R. Cammi, J. W. Ochterski, R. L. Martin, K. Morokuma, O. Farkas, J. B. Foresman and D. J. Fox, Gaussian 09, Revision A.02., Gaussian, Inc., Wallingford CT, 2016.

44 R. K. Harris, P. Hodgkinson, C. J. Pickard, J. R. Yates and V. Zorin, Magn. Reson. Chem., 2007, 45, S174-S186.

45 G. N. M. Reddy, D. S. Cook, D. Iuga, R. I. Walton, A. Marsh and S. P. Brown, Solid State Nucl. Magn. Reson., 2015, 65, 41-48.

46 G. N. M. Reddy, A. Marsh, J. T. Davis, S. Masiero and S. P. Brown, Cryst. Growth Des., 2015, 15, 5945-5954.

47 G. Wu, Z. Gan, I. C. M. Kwan, J. C. Fettinger and J. T. Davis, J. Am. Chem. Soc., 2011, 133, 19570-19573.

48 M. Hušák, A. Jegorov, J. Rohlíček, A. Fitch, J. Czernek, L. Kobera and J. Brus, Cryst. Growth Des., 2018, 18, 3616-3625.

49 L. Kobera, J. Czernek, M. Streckova, M. Urbanova, S. Abbrent and J. Brus, Macromolecules, 2015, 48, 4874-4881.

50 G. N. M. Reddy, J. A. Gerbec, F. Shimizu and B. F. Chmelka, Langmuir, 2019, 35, 15661-15673.

51 A. Samoson, Chem. Phys. Lett., 1985, 119, 29-32.

52 S. P. Brown and S. Wimperis, J. Magn. Reson., 1997, 128, 42-61.

53 S. P. Brown, S. E. Ashbrook and S. Wimperis, J. Phys. Chem. $B, 1999,103,812-817$.

54 F. Rodríguez-Llansola, J. F. Miravet and B. Escuder, Chem. Commun., 2011, 47, 4706-4708.

55 T. Cao, F.-T. Zhang, L.-Y. Cai, Y.-L. Zhou, N. J. Buurma and X.-X. Zhang, Analyst, 2017, 142, 987-993.

56 D. S.-H. Chan, H. Yang, M. H.-T. Kwan, Z. Cheng, P. Lee, L.-P. Bai, Z.-H. Jiang, C.-Y. Wong, W.-F. Fong, C.-H. Leung and D.-L. Ma, Biochimie, 2011, 93, 1055-1064.

57 F.-T. Zhang, J. Nie, D.-W. Zhang, J.-T. Chen, Y.-L. Zhou and X.-X. Zhang, Anal. Chem., 2014, 86, 9489-9495.

58 G. M. Peters, L. P. Skala and J. T. Davis, J. Am. Chem. Soc., 2016, 138, 134-139.

59 A. Mills, D. Hazafy, J. Parkinson, T. Tuttle and M. G. Hutchings, Dyes Pigm., 2011, 88, 149-155.

60 M. Wallace, J. A. Iggo and D. J. Adams, Soft Matter, 2015, 11, 7739-7747. 
61 M. Wallace, A. Z. Cardoso, W. J. Frith, J. A. Iggo and D. J. Adams, Chem. - Eur. J., 2014, 20, 16484-16487.

62 T. T. Herskovits and J. P. Harrington, Biochemistry, 1972, 11, 4800-4811.

63 A. Hirano, H. Tokunaga and M. Tokunaga, Arch. Biochem. Biophys., 2010, 497, 90-96.

64 J. Krzaczkowska, J. Gierszewski and G. Ślósarek, J. Solution Chem., 2004, 33, 395-406.

65 M. G. Sacerdote and J. W. Szostak, Proc. Natl. Acad. Sci. U. S. A., 2005, 102, 6004.

66 M. Maresca, A. Derghal, C. Carravagna, S. Dudin and J. Fantini, Phys. Chem. Chem. Phys., 2008, 10, 2792-2800.

67 M. Nishio, Y. Umezawa, J. Fantini and M. S. Weiss, Phys. Chem. Chem. Phys., 2014, 16, 12648-12683.
68 P. O. P. Ts'o, I. S. Melvin and A. C. Olson, J. Am. Chem. Soc., 1963, 85, 1289-1296.

69 P. O. Ts'o, Ann. N. Y. Acad. Sci., 1969, 153, 785-804.

70 G. M. Peters and J. T. Davis, Supramol. Chem., 2014, 26, 286-295.

71 R. K. Castellano, V. Gramlich and F. Diederich, Chemistry, 2002, 8, 118-129.

72 X. Tian-xiang and B. D. Anderson, Int. J. Pharm., 1990, 59, 45-55.

73 K. P. Madhusudanan, S. B. Katti and A. K. Dwivedi, J. Mass Spectrom., 1998, 33, 1017-1022.

74 H. Kuang, S. Wu, Z. Xie, F. Meng, X. Jing and Y. Huang, Biomacromolecules, 2012, 13, 3004-3012.

75 B. D. Anderson, M. B. Wygant, X. Tian-Xiang, W. A. Waugh and V. J. Stella, Int. J. Pharm., 1988, 45, 27-37. 